\title{
Disintegration per Minute per Milliliter
}

National Cancer Institute

\section{Source}

National Cancer Institute. Disintegration per Minute per Milliliter. NCI Thesaurus. Code C117970.

A unit of radioactive decay expressed in atoms of radioactive material that decay over a period of time equal to sixty seconds in a volume unit equal to one milliliter. 